\title{
The concept of chosen people in the construction and maintenance of Jewish identity
}

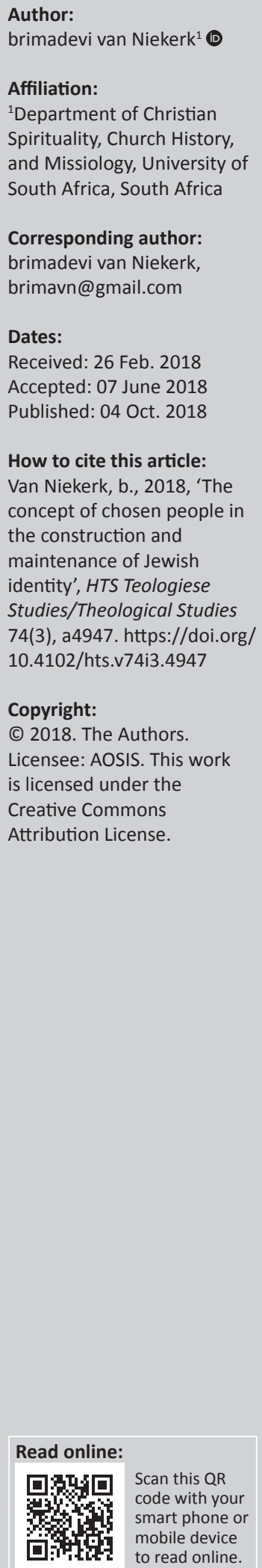

Jews, as a group, are able to withstand the disintegrative forces of modernity by upholding certain notions of self-identification which are rooted in their ancestral and religious history. One such notion around which Jews have formed their identity is the concept of chosen people which lends credence to their sense of belonging. However, the concept of chosenness may be offensive to those who are not Jews. The aim of this article, therefore, is to examine what may be considered objectionable about the concept, to explain its persistence in the world and to explore the foundations on which Jews, a minority group of people, have formed their identity. Although many researchers now understand the concept of chosen people from the perspective of history, nations and nationalisms, ethnicities and myth, there has been little sustained critique in the religious dimension of identity. This article attempts to make a contribution to the work on religious identity of Jews in South Africa by drawing on literature in history, sociology and religion. The article concludes that chosenness, because it can be as onerous to Jews as it is beneficial, need not necessarily imply superiority and that claims to being chosen are rhetorical and not verifiable outside the discourse in which such claims are made.

\section{Introduction}

For many years now, since I have been teaching introductory courses to Judaism at the University of Johannesburg, I always get a similar response from students in the first lecture on the overview of Jewish history and, in particular, when the notion of covenant and chosen people is discussed. This concept is always problematic and students protest disapprovingly at the idea of Jews being called the chosen people. ${ }^{1}$ What is it that students find prickly or offensive about this concept? How does an ancient idea still find contextual relevance for Jews today who are in the South African diaspora where religious traditions of myth are not enough and no longer agree with the contemporary scene? The aim, therefore, of this article is to examine the foundations on which Jews have formed their identity around the concept of chosen people and to explain its persistence in the world despite the effects of modernity; how is it possible when boundaries in the world have become so fluid and porous, when technologies, mass electronic communications, goods, services and the flow of people across the world increase in speed and ease, that Jews are able to withstand the effects of the modern world by maintaining and preserving an antique idea such as chosen people?

\section{Literature review}

In the literature on chosen people, there appears to be several works written from the perspective of history (Gitlin \& Leibovitz 2010; Gürkan 2009), nations and nationalisms (Smith 2003), theology (Novak 1995), myth (Allegro 1971; Leeming 2004) and other works from the point of view of religious diversity who offer a pluralist model (Knitter 2005; Kogan 2005).

In their book, The Chosen Peoples: America, Israel, and the Ordeals of Divine Election, Todd Gitlin and Liel Leibovitz show what effects of the concept of chosenness can have on those who believe in the idea. Writing predominately about the concept of chosenness among the Jews, they trace how the concept develops in diaspora, leading to Zionism and the present dilemma of Israel and Palestine, with the American notion of chosenness having its inception with the colonial settlers and their attitudes to the autochthon inhabitants, following with US support of the state of Israel. 'At its core', they argue:

the immensely influential Hebrew Bible is a story of a people who believe themselves to have been chosen by God - chosen, moreover, to live in a particular land. The notion of being chosen, whether a gift or a

1.It is perhaps important to mention that these students in the anecdote were born in post-apartheid South Africa, and though many would have already attended mixed schools, the stories from their parents' generation about exclusion and separation on the basis of racial superiority must surely play a part in their present worldviews and the formation of their identities. Most of the students profess to be Christians, with a small number of Muslims and Hindus, and a few who proclaim no religion. 
burden, is what fashioned them into a people, revived them in exile, demanded interpretation, and repeatedly plunged them into danger seemingly from the beginning of recorded time. (Gitlin \& Liebovitz 2010:1)

However, the concept of chosenness seems to perplex Israelis, Americans and especially Westerners, who are educated and secular and find it unreasonable to 'credit a biblical notion for the birth of nations' (Gitlin \& Liebovitz 2010:191-192). They argue that the issue of chosenness:

would seem best left to the true believers, the zealous minority whom in both countries, have fashioned theologies of divine election into agendas of narrowness and aggression. But it would be naive to think that either Americans or Israelites can walk away from the extraordinary, entrancing, ancient, deep and - in so many ways - odd idea that we, or began as, God's chosen people. (Gitlin \& Liebovitz 2010:192)

Gürkan (2009:185-186), too, has attempted to understand the nature of the Jewish insistence on 'chosenness' and the interaction between the idea of chosenness and the shape of Jewish religion and Jewish identity. Gürkan (2009:185-186) has showed that the idea of chosenness is an essential element in Jewish theology and Jewish memory forming an important constituent of Jewish identity, which has been interpreted in divergent ways, not only in different Jewish movements or congregations but also in different epochs. What has been common to all those various Jewish interpretations of chosenness, however, is a sense of 'uniqueness', as coupled most of the time with a feeling of 'superiority' (Gürkan 2009:185-186).

Anthony D. Smith (2003) advances the idea that ethnicity, commonality, economic interest, political stability and language cannot explain the persistence of national identity. Only long-standing religious symbols and rituals can account for the endurance of religious collectives. For Smith, national identity operates as 'a form of culture and a type of beliefsystem whose object is the nation conceived as a sacred communion' (Smith 2003:18). Drawing on Émile Durkheim's (1915) functional definition of religion, Smith views the distinction between the sacred and the profane as elements that undergird national culture. He assesses the ways in which myths of ethnic election serve as a mechanism for socio-cultural survival and a stimulus for ethno-political mobilisation. He also indicates how the concept of the chosen people intensifies the identification of the community with its homeland. By using the ethno-symbolic approach and history, Smith (2003:viii) is able to point to the sacred sources of national identity. The events of history between the 1980s and the 1990s marked a time when there was 'notable religious revival, a spate of "religious nationalisms"' and heightened ethnic antagonisms fanned by attachments to sacred objects, whether in Ayodhya, Jerusalem or Kosovo. They reveal that 'symbolic' issues stir collective passions as much as purely economic or political grievances (Smith 2003:viii).

From Vital's (2001:398-399) perspective, the Jews, 'historically, were a "nation" in every important sense of that infinitely tricky and provocative term' and it cannot be denied. Some historians have stated that it was the Jews, together with the Greeks, who were responsible for creating the concept and who themselves portrayed the first type of the phenomenon of nation:

That, of course, is not the whole of the - and their - story. That the religion and culture (high as well as low) of the Jews were intimately and inextricably bound up with their nationhood over very many centuries is beyond question. What can be seriously, if somewhat fruitlessly, debated is only the subsidiary question whether their ancient faith should be seen primarily as the instrument of their national preservation, or contrariwise, whether it is their people hood that should be seen as the means whereby their religion was defended and preserved, and not without success, against, successive, near fatal onslaughts by pagan, Christian, and Muslim rivals. (pp. 398-399)

Vital (2001:398-399), of course, is concerned about the persistence of the Jews as a separate and distinct group of people. He is not optimistic. 'Where', he says:

there was once a single, if certainly a scattered and far from monolithic people - indeed, a nation - there is now a sort of archipelago of discrete islands composed of rather shaky communities of all qualities, shapes, and sizes, in which the Island of Israel, as it were is fated increasingly to be in a class by itself. (p. 399)

Novak (1995:xi) takes on the fundamental question of what it means to be a Jew and addresses it more globally to include all Jews in the world together with the question of what it means to be chosen by God. Novak approaches his subject matter by examining the theology of election in the light of post-Enlightenment theory; the question of who did the choosing: was it God or Israel, and relating this to the modern rejection of revelation; and can non-Jews be part of the elect people? It is the question as to whether or not non-Jews can be part of the elect people which is the concern of this article. The very fact that Novak refers to those who are not in a covenantal relationship with the God of Israel as non-Jews already points to a discriminatory view of others. Like the term 'non-European' in apartheid, which defined the identity of people by what they are not - that is, in the negative - and not what they are, similarly, the term 'non-Jew' implies otherness in relation to what Novak sees as the benchmark of religious identity. This makes Hindus, Christians, Buddhists and African Traditionalists all non-Jews. So already in his discussion on chosen people, there is an exclusionary force inherent in the way in which the un-chosen people are referred to - to use an opposite of the term - in understanding themselves as Jews. The idea of Jewish chosenness would, in such an interpretation, thus come to suggest that Jews must see themselves as superior, as picked out from the rest of humanity because they are special, or better, or more deserving, than any other group of people.

Kogan (2005) has offered a refreshing alternative to the narrow interpretation of Novak's theology. He asserts that:

[f]rom its inception, Israelite faith has been characterised by a balance between the particularist and universalist themes. 
Abraham was called to be the father of a 'great nation' centred in a particular holy land. But the ultimate meaning of that nation's life was a universal one. In different ages of its history, Israel has stressed one or the other of these aspects of its divine commission. (p. 105)

Kogan (2005:105) has suggested that there should be 'new and enlightened ways' of interpreting these ancient ideas on Judaism in a contemporary world. 'Conceived narrowly, Jewish particularism could lead us to conclude that God is interested exclusively in one "chosen people," while remaining indifferent to the rest of humanity'. He calls for a broad pluralistic approach in the interpretation of the notions of 'particular' and 'universalistic' which will allow Jews to live harmoniously with all other religions in the world. 'Religious exclusivism', says Kogan (2005:105), 'is nothing more than corporate egoism of creed and community'. Kogan (2005) wants a pluralism that should include a:

humane prophetic witness, which will enable us to deal with our fellow beings of different faiths as well as with our own people, valuing distinctions of culture and belief rather than condemning or denigrating them ... Instead of being the chosen people, my people begin to see themselves as $a$ chosen people. (p. 114)

This radical shift in how to view chosen people changes how Jews see themselves in the world: as one community among many.

Similarly, Cohn-Sherbok (2005) calls for the doctrine of chosen people to be revised from a 'pluralistic' viewpoint:

Throughout history the belief that Israel is God's chosen people has been a central feature of the tradition, through its election, Jewry believed it had been given a historic mission to bear divine truth to humanity. God's choice of Israel thus carries with it numerous responsibilities: Israel is obligated to keep God's statutes and observe divine laws, and in doing so, the nation will be able to persuade others that there is only one universal God. By carrying out this task, Israel is to be a light to the nations. (p. 130)

And I think here Cohn-Sherbok (2005) is being honest about how much of the status of Jews in the covenantal relationship with their God is really self-made, or constructed, if you like, when he says:

... the conviction that God has selected a particular people as God's agent is nothing more than an expression of the Jewish people's sense of superiority and impulse to spread its religious message. In fact, however, there is simply no way of knowing if a specific people stands in a special relationship with the Divine. (p. 130)

Like Kogan, Cohn-Sherbok (2005) calls for a reorientation in how Jews view themselves in relation to other traditions:

With a shift from inclusivism to pluralism, there is no longer any need to interpret other religions from a Judeo-centric standpoint; rather, with the Divine at the centre of the universe of faiths, Jewry can acknowledge the inevitable subjectivity of all religious beliefs, including those contained in the Jewish heritage. (p. 132)
John M. Allegro (1971) and David Leeming (2004) both challenge the conventional wisdom surrounding this concept and place the myth within the context of its origins. Leeming (2004) says that:

Jews, and later Christians and Muslims, tend to take the monotheistic god as a literal rather than a metaphorical fact. For Jews especially, whose religion and nationhood are so intricately tied to a mythology that stresses lineage and the exclusivity of the race or tribe, the perceived reality of a covenant with the deity in the mythological past continues to affect the concept of nationhood and land rights in the Middle East today. (p. 89)

\section{A brief history of Jews in South Africa ${ }^{2}$}

Although Jews have been in South Africa since 1652 when the Dutch East India Company established a permanent settlement in the Cape, their official presence and their early expressions of faith were marked by the formation of the first synagogue in the Cape colony in 1841, thereby inaugurating the social and the religious aspects of their organisational structures in settlement and consolidating their identity as Jews in South Africa. The establishment of Jews in the colony meant not only that were there new religious institutions being created, but also that Jewish presence would forever change the religious and ethnic landscape of the country adding to the pantheon of religious pluralism. However, three distinct waves of migration between the middle of the 19th and 20th centuries increased the presence of Jews in South Africa. They came from the provinces within the Pale of Settlement, situated in territories belonging to subjugated minority populations, which included Poles, Byelo-Russians and Lithuanians who were escaping deportations, pogroms, natural disasters, and economic poverty (Gershater 1955:64-84). Although persecution and hardship precipitated the movement of Jews out of Europe, it was also the 'magnetic force of tales of fabulous opportunity and wealth in South Africa' that Jews found enticing (Hellig 1984:98). Most of the Jews who came to South Africa were of Lithuanian origin who shared similar backgrounds and experiences which gave them a sense of relative homogeneity (Arkin 1984:80) and an esprit de corps.

For just over a century and a half since their arrival in South Africa, Jews have become a firmly established presence holding prominent positions in politics, arts, literature and the economic sector. However, although Jews participated in the public life of South Africa, it was done as private citizens of the country and not as a collective. For example, writes Cohen (1984:30), Jews voiced their disapproval of apartheid as individuals and not as a community. This phenomenon is a characteristic of minority groups, as G. Shimoni (quoted in Cohen 1984:30) says, 'What was at stake was simply the preservation of full rights for Jews as White citizens of South

2.The country South Africa came into existence in 1910 when the British colonies of Natal and the Cape, and the Boer republics, the South African Republic and the Natal and the Cape, and the Boer republics, the South African Republic and the Orange Free State were joined as one country. In this article, as a matter of convenience, where South Africa in the period before 1910 is mentioned, refers to the geographical areas which at the time were in fact part of either the colonies or the republics. 
Africa and the unhindered free existence of a Jewish communal life'. So although Jews have embraced South African culture by integrating ${ }^{3}$ into the social and occupational networks, they remain un-assimilated. ${ }^{4}$

It is interesting to note that the people who played hosts to the Jews, the Afrikaners, were Calvinists who identified their own history with that of Israel in the Old Testament and, like the Jews, viewed themselves as a Chosen People with a divine mandate which at the same time provided them with 'motivation' in terms of their 'self-understanding' (Du Toit 1983:925). ${ }^{5}$ Du Toit (1983:920) argues that the origins of Afrikaner nationalism and its associated racial ideologies and, thus, of the apartheid order imposed by the National party governments on South African society in recent times have often been ascribed to this 'obdurate strain of "Calvinism"'. According to this view, he says, the Afrikaner founding fathers brought with them to the Cape the basic tenets of 17th-century Calvinist thought, in the isolated frontier conditions of trekboer ${ }^{6}$ society which survived for generations as a kind of 'primitive Calvinism'. The idea took hold in the early 19th century and provided much of the rationale for the Great Trek. Thus, the Voortrekkers and the Republican Afrikaners conceived of themselves as a chosen and covenanted people, like the Israelites of the Old Testament, which has been used to explain and justify racial inequality and repression in latter-day Afrikaner-dominated societies (Du Toit 1983:920).

From the side of the Jews, it would appear, according to Saron and Hotz (1955), that the Jewish immigrants found their new location conducive to their Zionist pursuits because, as they put it, the:

Dutch/Afrikaner segment of the white population was particularly attached to the Hebrew Bible and for generations, as a result of their own historical experiences, had felt a close affinity with 'the Chosen People'. (pp. 27-28)

Jews then were able to pursue their own ethnic separation and identification following their Dutch or Afrikaner hosts, thereby inserting and aligning themselves with the white people in the colony, linked by their religious and ideological

3.The word 'integration' is used here to suggest that Jews, a minority group, inserted themselves into a pre-existent society 'while retaining its own culture and religion, adapts itself to and is accepted as a permanent member of the majority society in all the external aspects of association' (Rose 1969:24).

4.In comparing Jewish communities in terms of their distinctiveness, Sharot (1976:2) uses the term 'acculturation' which he defines as the change of the minority's culture to that of the 'host' or 'core' society. De-acculturation is defined as the culture to that of the 'host' or 'core' society. De-acculturation is defined as the change of the minority's culture away from that of the "host' or 'core society. The major difference between a Jew and his non-Jewish neighbour has historically been a religious one, but Jewish communities may be compared along a continuum, ranging from those which retain or reinforce the distinctiveness of their religion to those which adopt, or take as models, the religious beliefs, practices and organisational forms of the non-Jewish environment.

5.Apart from the Christians and Jews, Islam, the other monotheistic religion, also believes that they are the Chosen ones of God. Other nations such as India, Spain Germany, France, Britain and the United States also believe in their Chosen legacy (see Beker 2008:1).

6. Trekboers were essentially semi-nomadic farmers who frequently moved (probably every few years) to find more or better land, or because they were pushed by other trekboers seeking land and grazing. So literally speaking, a trekboer is a trekking farmer where trekking means arduous journey, inspanning (from the Dutch or farmer where trekking means arduous journey, inspanning (from the Dutch or
German to unite or fasten) their oxen to pull their ox-wagons with all their worldly possessions to some other piece of unclaimed land. expression of faith. South African Jews, in the main, profess to be either Liberal, Orthodox, Conservative, Reconstructionist or Reformed.7 The differences between these strands of Judaism are essentially doctrinal. But they are also divided between those urging assimilation and those intent on remaining apart from the larger society. Orthodox Jews represented the forces of traditionalism, with a demand for the strict observance of Jewish law (halach). Reform Jews are an assimilative response to Orthodox traditionalism who sought accommodation with the outside world and were receptive to modernisation and Enlightenment thought. Between these poles, Conservative Jews sought to find a middle ground by seeking to balance the demands of traditionalism against the benefits of modernity.

Despite the differences that appear to divide Jews doctrinally, they are nevertheless linked by their early sacred history. According to Holladay (1995:28-31), Yahweh entered into a covenant with the people of Israel (understood as a community and not as individuals), using the form of the suzerainty treaty common between suzerain kings and vassal states in the ancient Near East of the time. ${ }^{8}$ The covenant between God and Israel mediated by Moses at Sinai is the conditional covenant par excellence in the Old Testament. This covenant was understood to bind Yahweh and Israel together, giving rise to the often repeated formula, 'I will be your God, and you shall be my people' (Ex 6:7; Lv 26:12; Deut 29:13) (Holladay 1995:26-27).

The form and nature of this covenantal metaphor is of a legal relationship between two parties, Yahweh and Israel, neither of whom can coerce the other to perform in terms of the agreement, but each of whom has claims against the other. Israel can choose to be unfaithful to Yahweh, as it frequently is, and Yahweh, in turn, can punish Israel for this and could even withdraw from the covenant if Israel takes it for granted. The underlying metaphor of the covenant is that of Yahweh as the king of Israel, responsible for the well-being of Israel in return for its complete loyalty. As Yahweh is separate from the created world, he cannot simply be a projection of Israel's national goals, and the relationship between these two separate parties is therefore not a relationship between individuals, but one between Yahweh and the people of Israel as a community (Holladay 1995:26-27).

However, it is important to take note that this aspect of Jewish sacred history is not just something that happened a long time ago, but it continues to occupy a very salient position in the traditions and liturgy of the Jewish people today. Beker (2008:20) says that when a Jew participating in a service is

7.When viewed from the outside, Jews are seen as a single well-defined idea of community. This is not really the case when viewed from the inside; Jews with their various denominational divisions and their ideological differences, for example regarding Zionism, may threaten group cohesiveness. And yet, when faced with anti-Semitism, they stand together as one community.

8.The Hebrew word for 'covenant', berrit, gave rise to the Yiddish word bris, 'circumcision'. In the Old Testament, beritit is used in various ways. It may refer to a relationship on a human level, between two unrelated individuals or communities. In that usage, it may refer to a close friendship and permanent loyalty between two In that usage, it may refer to a close friendship and permanent
individuals probably sealed by an oath (Holladay 1995:28-31). 
summoned to read the Torah, he recites the blessing: 'Blessed art thou, O Lord our God king of the universe, who has chosen us from all peoples and hast given us thy Torah'. These prayers, he says, are rendered in the daily prayers of Jews which are then repeated in the reading of the Torah, 'twice during the week and twice during the Sabbath and during festivals'. This clearly points to the prominence of these invocations and the need to repeat and affirm daily the relationship between Israel and its people. Furthermore, this covenant is 'unbreakable' and it also carries with it a 'great responsibility' and what Beker (2008:21) seems to think is a 'resultant hardship on the Jews'. For Jews, the response to chosenness means that they must keep the laws of the commandments and 'in the process strive to perfect themselves and the world' - a dialectical tension between religious identity and civic obligation (Beker 2008:21). And the failure to keep the proper response to being chosen, which is inevitably regarded as transgressive, results in punishment.

As a single group calling themselves Jews, they are absorbed in their beliefs and practices which relate to ideas about God, revelation and man, which they express through obedience to the commandments and which help define the relationship between the individual and God and the individual and fellow individuals. Despite being a minority group, Jews are relatively well-accepted within the larger South African society, yet remain highly acculturated and socially homogenous. With the decimation of their ancestral roots, the ravages of war, pogroms, displacements and so on, one would think that the Jews would have just easily taken their place among other South Africans. But they did not. Instead what they did was to re-create and re-form themselves in their new environment. Writing on the religious commitment and observance of diaspora Jews, Hellig (1984:98) argues that the South African Jews are the '... most organised diaspora community in the world' who have been able to maintain one of the most basic features of orthodoxy, namely separateness. Hellig (1984:98) argues that there never really was a 'melting pot' effect in South Africa because 'there has been little desire to obliterate the distinctive cultural patterns' which began in Eastern Europe. That may be so, but Jews surely take on plural identities for they are, at once, Jews, in terms of their ascribed identities, and then South Africans in terms of a larger identity.

However, Jews have become less and less distinguishable from other South Africans in dress, speech, educational patterns and work lives. Jewish neighbourhoods are becoming fewer and fewer, which raises the question of how Jews are able to maintain this relative isolation and homogeneity within a larger South African community where Jews are in contact with people of different religious persuasions and backgrounds. How, then, do Jews live between their accountability to the dominant social order and, at the same time, their accountability to the laws of their religion which calls for the maintenance of their distinctive identity as God's chosen people?

\section{Religion as social identification}

There are various 'markers' or 'stereotypic signatures' that groups use to define themselves (Paden 2009:37). For example, the role of patron saints such as the Mexican Virgin of Guadalupe in the construction of a national identity; the role of female circumcision as a strategic community membership sign in African communities; the widely recognised Western wall for Jews; or for that matter, the manner in which the Sunnis and Shi'ites hold their arms while performing daily prayers (Paden 2009:37). Although these may be non-discursive markers of religious identity, they certainly have meaning for the groups in which they are practiced in relation to whatever they hold as sacred. However, if one sees religion in the words of John Hick (2005) as 'bounded entities', then each should possess a:

unique totality of forms of spiritual practice, revered scriptures, treasured creeds, stories and myths, familiar symbols, systems of doctrine, moral codes, great paradigmatic figures, remembered histories, cultural ethos, [and] authority figures. (pp. 3-12)

These function as markers in the definition of groups.

Jewish identification, like most forms of minority group identification, is based on notions of common origin and tradition. It similarly, argues Geismar (1954:34), serves to provide a defence against the pressures from the majority. It is unique, however, in its derivation from a religious culture which has been subjected to many theological and secular interpretations and in its dependence on a homeland which was recreated after having been a memory for nearly 1900 years (Geismar 1954:34). How, though, given our understanding of the peculiar history of the Jews in which their identities are interwoven, do we capture the many ways in which religious ideas and structures help make sense of their world? Whatever concept we choose to understand the notion of chosen people among the Jews, however, it must be couched in terms of identity and community.

The word 'identity', say Brubaker and Cooper (2000:2), has a long history in Western philosophy beginning with the Greeks all the way through to 'contemporary analytical philosophy'. The introduction of 'identity' into social analysis and its initial diffusion in the social sciences and public discourse occurred in the Unites States in the 1960s, which was popularised by the work of Erik Erikson who was responsible, among other things, for inventing the term 'identity crisis'. However, the notion of identification was pried from its original, specifically psychoanalytic context (where the term had been initially introduced by Freud), and linked to ethnicity on the one hand and to sociological role theory and reference group theory on the other (Brubaker \& Cooper 2000:2-3). Identity, captured by Jenkins (2008:3) without the jargon, 'is the human capacity - rooted in language - to know "who's who" (and hence "what's what")'. This entails knowing:

who we are, knowing who others are, them knowing who we are, us knowing who others are, and so on: a multi-dimensional 
classification or mapping of the human world and our place in it, as individuals and as members of collectivities. (Brubaker \& Cooper 2000:3)

The term then may be conceptualised in three ways: selfunderstanding, ${ }^{9}$ self-interest and social location. Identity in this instance 'denotes a fundamental and consequential sameness among members of a group or category' (Brubaker \& Cooper 2000:7).

The term, when used in common parlance and political practice, suggests a common sense meaning, identified by Brubaker and Cooper (2007:7) as something 'all people have, or ought to have, or are searching for'; 'something all groups (at least groups of a certain kind - e.g., ethnic, racial, or national) have, or ought to have'; and 'something people (and groups) can have without being aware of it'. In this sense, identity is something yet to be 'discovered', and 'something about which one can be mistaken' (Brubaker \& Cooper 2000:7).

However, identification seems to be unavoidably bound up with social categorisation formed through social relationships and social structure. It is only through recognising what one is not that a person constructs their own sense of self and belonging (Jenkins 2008). As such, difference and familiarity are crucial factors in the identification process and we tend to draw social boundaries accordingly (Barth 1969). The boundary very often becomes entangled with moral evaluations - that difference is threatening, or in some way worse (Douglas 1966). And as Martin (2012:45) says, societies are largely constituted by systems of classification and related social roles and behavioural practices. All societies are made up of categories that distinguish between who is included and who is excluded, and, in addition, categories that distinguish different social classes or social positions within the group. So, 'who we are, or who we are seen to be, can matter enormously' and 'although identification always involves individuals, something else - collectivity and history - may also be at stake' (Jenkins 2008:3).

Can we call Jews an ethnicity because of their collective identity? To begin with ethnicity may be defined as a:

collectivity of people who (a) share some patterns of normative behaviour and (b) form a part of a larger population, interacting with people from other collectivities within the framework of a social system. (Cohen 1974:ix)

The term 'ethnicity' refers to the degree of community by members of the collectivity to these shared norms in the course of social interaction. Cohen (1974:x) argues that this definition is quite wide so that it may even include those collectives that are not seen as an ethnicity. By patterns of normative behaviour, Cohen (1974:x) means the symbolic

9.The term 'self-understanding', which may take many forms, does not imply distinctively modern or Western understanding of the 'self' as a homogenous, bounded or unitary entity. In some settings, people may und bounded or unitary entity. In some settings, people may understand and experience themselves in terms of a grid of intersecting categories, and in others, in terms of web of connections of differential proximity and intensity, and hence the importance of seeing self-understanding and social locatedness in relation to each other and of emphasising that both the bounded self and the bounded group are culturally specific rather than universal forms (Brubaker \& Cooper 2000:17-18). formations and activities found in such contexts as kinship and marriage, friendship, ritual and other types of ceremonies. The term 'ethnicity', however, cannot be used to denote:

cultural differences between isolated societies, autonomous regions, or independent stocks of populations such as nations within their own national boundaries. The differences between the Chinese and the Indians, considered within their own respective countries, are national not ethnic differences. But when groups of Chinese and Indian immigrants interact in a foreign land as Chinese and Indians they can then be referred to as ethnic groups. Ethnicity is essentially a form of interaction between culture groups operating within common social contexts. (p. xi)

Cohen (1974:xii, italics in the original) argues that when scholars explain the concept of ethnicity in terms of history, motivation, primordial ideas or the psychology of identity, 'there is a tendency to posit ethnicity as a strategy manipulated by individuals to advance their personal interests and maximise their power'. The difficulty with this kind of explanation, he continues, 'is that it is one sided and cannot account for the potency of the normative symbols which the individual manipulates in his struggle for power' (1974:xii). The individual, he argues, must 'pay the price by participating in the group's symbolic activities and by a measure of adherence to the group's aims' (1974:xii).

Ethnicity could also be explained in terms of process in time. In this view, ethnicity is often associated with migrancy and is taken to be the process of adjustment and settlement into the host settlement and its absorption as members into the new society. One of the difficulties of this approach, argues Cohen (1974):

is that it is often not very clear whether one is concerned with a historical process or a cyclical one. For while it is true that many migrant communities, or ethnic groupings forming a state, go through a process of mutual adjustment and/or of integration, and in the process lose their cultural identity, there are many situations where the reverse can occur. Here a group adjusts to the new situation by reorganising its own traditional customs, or by developing new customs under traditional symbols, using traditional norms and ideologies to enhance its distinctiveness within the contemporary situation. As time goes on the group will become more and more distinct, sometimes even reviving old customs. (p. xiv)

This view encapsulates the position of the Jews in South Africa very accurately and is helpful in clarifying the nature of socio-cultural change and adaptation.

What I have been theorising about so far reflects only the utopian sense of identity in collectives and how they work. What of conflict and violence and divisions in groups? In an important collection of essays, Kim and Kollontai (2007b) address the significance of religion in the re-shaping of community identities. When it comes to religious conflicts, they argue, though in most cases the issues are not exclusively 'religious' and are often entwined with other complicated political and social matters, the situation becomes more acute 
when religious beliefs endorse or reinforce the legitimisation of violent action against others. For example:

in conflict between communities, fundamentalist attitudes to other beliefs often lead to aggressive approaches to others. This is because fundamentalists tend to produce a self identity that has been threatened, made anxious and uncertain and reacts aggressively' or has 'such total and unassailable aims and faith that they can no longer accept other convictions and attitudes alongside their own'. (Küng \& Moltman 1992 quoted in Kim \& Kollontai 2007b:1-2)

It would not be an exaggeration to say that most contemporary conflicts are somehow related to religious, as well as ethnic and political, identities of different communities, and we witness conflicts driven by fundamentalist religious attitudes towards identity' (Kim \& Kollontai 2007b:2). 'And there is a good reason for this kind of attitude' as Kim and Kollontai (2007b:2) observe that, 'aspects of community identity formulated out of religious commitment tend to be far deeper and more consolidating than that from any other source'. Writing about religion and identity of the Maori and Pakeha in Australia, Mol (1982:1) argues that in any society wholeness (or identity) is constantly jeopardised by fragmentation, conflict or, more generally, change. The fixed (identity) is constantly 'unglued' by the fickle (change). The identity model treats religion as one of the means to hold together ('fix' or stabilise) what otherwise would fly apart (through the fickleness of ever-present change) (Mol 1982:1).

And yet Claire Mitchell's (2005:3) case study on personal and group identification among Catholics and Protestants in Northern Ireland has showed that the conflict between these two groups is not primarily about religion revolving around 'doctrinal disputes', but that religion functions merely as a 'badge of ethnic difference'. Mitchell (2005:4) concludes that people's religious beliefs and practices, values and structures 'help construct ideas about self and others in an uncertain and divided political world'. 'Religion', she says, 'is not just a boundary marker, but that it often gives meaning to the boundary wall' (Mitchell 2005:4). This certainly provides an interesting way to view the concept of chosen people; it acts not just to separate the 'them' from the 'us', but to strengthen the meaning system for the group itself.

Hence, as Rex (1993:18) says, 'religious beliefs of these kinds provide a basis for group formation and for the mobilisation of these groups for social and political conflict and cooperation'. The problem of the social function of religious beliefs is then seen as one of its functions in relation to a specific historical and geographical context. But religions survive their original historical context, and ethnic and religious groups migrate to wholly different contexts. In these circumstances, one must consider both their continuing debate about the circumstances in their point of origin and their changing ideas as they relate to new contexts. Thus, in contemporary European societies, today there is a wide range of religious and ethnic groups who develop their beliefs and practices not merely in relation to the present world but also 'in relation to past and distant social and political contexts' (1993:19).

\section{Conclusion}

I set out to examine whether the antipathy that post-apartheid students in an introductory course to Judaism felt for the concept of Jews as a chosen people, and whether their view that it implies discrimination, is justified. An argument is advanced that if the notion of chosenness is understood to arise from a contractual arrangement between Yahweh and Israel, in which rights and obligations exist for both parties, the concept need not offend. In contrast to this, if Jews refer to people not in a covenantal relationship to God as being non-Jews, then this description, which negates what people are by emphasising what they are not, may well be seen to be offensive and exclusionary, and thus denoting Jewish superiority. This leaves open the question of whether the first-year students were entitled to object to the concept of chosenness.

Most groups are bound together by what they are and what they do and a certain specialness on their part or even certain requirements that are placed upon them. And this might be sufficient for some members of a group, but unfortunately there will always be people who seek to enhance their sense of belonging not by emphasising what they are but by emphasising what they are not. And when one emphasises what one is not, then one possibly suggests that others are inferior or lesser beings, and for many people, the negative view of others has a greater power of cohesiveness because it is the sense of what one is not rather than what one is. And when this self-identification of a discrete group is rooted in the ancestral and religious history of a people, then it is an even more powerful force in the construction and maintenance of identities. However, more empirical research is needed to test these theories in a community where Jews live and have their being, such as in Norwood in Johannesburg or Claremont in Cape Town - a whole lot more can be known about religion and community and how this concept functions in a real-life context.

\section{Acknowledgements Competing interests}

The author declares that she has no financial or personal relationships which may have inappropriately influenced her in writing this article.

\section{References}

Allegro, J.M., 1971, 'The chosen people', Panther Books Limited, Herts, UK.

Arkin, A., 1984, 'The Zionist dimension', in M. Arkin (ed.), South African Jewry: A contemporary survey, Oxford University Press, Cape Town.

Barth, F., 1969, 'Introduction', in Ethnic groups and boundaries: The social organization of culture difference, pp. 9-38, Unversitets Forlaget, Bergen.

Beker, A., 2008, 'The chosen: The history of an idea, the anatomy of an obsession', Palgrave Macmillan, New York, N.Y.

Brubaker, R. \& Cooper, F., 2000, 'Beyond identity', Theory and Society, vol. 29, pp. 1-47, Kluwer Academic Publishers, Netherlands. 
Cohen, A., 1974, 'The lesson of ethnicity', in A. Cohen (ed.), Urban ethnicity, pp. ix$\mathrm{xxv}$, Tavistock Publications, London.

Cohen, S., 1984, 'Historical background', in M. Arkin (ed.), South African Jewry: A contemporary survey, pp. 1-22, Oxford University Press, Cape Town.

Cohn-Sherbok, D., 2005, 'Judaism and other faiths', in P.F. Knitter (ed.), The myths of religious superiority: A multifaith exploration, pp. 119-134, Orbis Books, Maryknoll, NY.

Douglas, M., 1966, Purity and danger, Routledge \& Kegan Paul, London.

Durkheim, É., 1915, The elementary forms of the religious life, The Free Press, George Allen \& Unwin Ltd., Glencoe.

Du Toit, A., 1983, 'No chosen people: The myth of the Calvinist origins of Afrikane Nationalism and racial ideology', The American Historical Review 88(4), 920-952, viewed 24 March 2017, from http://www.jstor.org/stable/1874025

Geismar, L., 1954, 'A scale for the measurement of ethnic identification', Jewish Socia Studies 16(1), 33-60, Indiana University Press Stable, viewed 26 May 2013, from http://www.jstor.org/stable/4465208

Gershater, C., 1955, 'From Lithuania to South Africa', in G. Saron \& L. Hotz (eds.), The Jews in South Africa: A history, pp. 64-84, Oxford University Press, London.

Gitlin, T. \& Leibovitz, L., 2010, The chosen peoples: America, Israel, and the ordeals of divine election, Simon \& Schuster, New York.

Gürkan, L.S., 2009, The Jews as a chosen people: Tradition and transformation Routledge Jewish Studies Series, Routledge, London.

Hellig, J., 1984, 'Religious expression', in M. Arkin (ed.), South African Jewry: A contemporary survey, pp. 95-115, Oxford University Press, Cape Town.

Hick, J., 2005, 'The next step beyond dialogue', in The myth of religious superiority: Multifaith explorations of religious pluralism, pp. 3-12, Orbis Books, Maryknoll, NY.

Holladay, W.L. 1995, Long ago God spoke: How Christians may hear the Old Testament today, Fortress Press, Minneapolis, MN.

Jenkins, R., 2008, Social identity, 3rd edn., Routledge, London.
Kim, S.C.H. \& Kollontai, P., (eds.), 2007a, Community identity: Dynamics of religion in context, T\&T Clark, London.

Kim, S.C.H. \& Kollontai, P., 2007b, 'Introduction', in S.C.H. Kim \& P. Kollontai (eds.), Community identity: Dynamics of religion in context, T\&T Clark, London.

Knitter, P.F. (ed.), 2005, The myth of religious superiority: Multifaith explorations of religious pluralism, Orbis Books, Maryknoll, NY.

Kogan, M.S., 2005, 'Toward a pluralist theology of Judaism', in The myths of religious superiority: A multifaith exploration, Orbis Books, Maryknoll, NY.

Leeming, D., 2004, Jealous Gods and chosen people: The mythology of the Middle East, Oxford University Press, New York.

Martin, C., 2012, A critical introduction to the study of religion, Equinox Publishing Limited, Sheffield, UK.

Mitchell, C., 2005, 'Behind the ethnic marker: Religion and social identification in Northern Ireland', Sociology of Religion 66(1), 3-21.

Mol, H., 1982, The fixed and the fickle: Religion and identity in New Zealand, Wilfrid Laurier University Press, Waterloo, Ontario, Canada.

Novak, D., 1995, The election of Israel: The idea of the chosen people, Cambridge University Press, Cambridge.

Paden, W.E., 2009, Reappraising Durkheim for the study and teaching of religion. in P.B. Clarke (ed.), The Oxford handbook of the sociology of religion, pp. 31-47, Oxford University Press, Oxford, NY

Rex, J., 1993, 'Religion and ethnicity in the metropolis', in R. Barot (ed.), Religion and ethnicity: Minorities and social change in the Metropolis, pp. 17-26, Kok Pharos Publishing House, Kampen, the Netherlands.

Saron, G. \& Hotz, L., 1955, The Jews in South Africa: A history, Oxford University Press, Cape Town.

Sharot, S. 1976, Judaism: A sociology, Holmes \& Meier Publishers, Inc., New York.

Smith, A.D., 2003. Chosen peoples, Oxford University Press, New York.

Vital, D., 2001, 'Judaism and Zionism. The future of the Jews: A people at the crossroads?', in J. Neusner \& A.J. Avery-Peck (eds.), The Blackwell reader in Judaism, pp. 395-410, Blackwell Publishing, Oxford, UK. 